\title{
Intrinsic Value of Incentives Compared To Salaries: Can Organization Stop Paying Salaries?
}

Valliappan Raju ( $\square$ valliappan008@gmail.com )

https://orcid.org/0000-0003-1989-4502

Article

Keywords: Compensation, Equity Theory, Human Resource Practices, Incentives, PLS-SEM Analysis, Rewards

Posted Date: September 27th, 2021

DOl: https://doi.org/10.21203/rs.3.rs-698507/v1

License: (c) (7) This work is licensed under a Creative Commons Attribution 4.0 International License. Read Full License 


\section{Abstract}

This research weighs significantly on challenging the present practice of compensation and rewards. Traditionally or conventionally, the organization reciprocates the gratitude to their employees in monetary terms. Non-monetary rewards being an exclusive section, it is not discussed in this research paper. Among the direct rewards, whether the companies should practice compensating their employees a fixed salary or pay only incentives for the tasks that are achieved? this question may not be welcomed by any employee as it touches the sensitive quotient. Nevertheless, organizations need to understand the right practice in the right era by implementing an intelligent framework. Equity Theory developed by Adams is laid as a foundation to encounter the present unfair reward system. Concurrent mixed-mode method research is done with 162 respondents (quantitative) and 15 respondents (qualitative). Multivariate analysis using SmartPLS 3.3.3 is executed to assess the measurement model and structural model to analyze the covariance between the constructs. The outcome of research claims that it is an ideal practice to implement task-based incentives in organizations rather than paying fixed salaries irrespective of the size or productivity of companies.

\section{Key Questions}

1. Whether the companies should practice to compensate their employees with a fixed salary or pay only incentives for the task that are achieved?

2. Is it sustainable for companies to keep paying fixed salaries when there is a strong option of task-based incentive is available?

\subsection{Introduction}

The synergy in the organization is discussed intensely among scholars as a crucial element of human resource management practices (HRMP). The collective objective has to be singular and the motive to achieve it has to align with the rest of the fraternity (Hewett \& Shantz, 2021). However, it is understood that the common goal has always (majorly) been subsided for personal accomplishments. Multinational corporations, small and medium enterprises, public institutions usually face the problem of optimizing personnel productivity and their corresponding compensation (Lee \& Kray, 2021). In the 1960s large organizations devised strategies to motivate their employees with rewards, so that the collective objective on organizational success could be achieved. The strategy in Apple Incorporation was not only to cultivate patriotism in the organization but was also to identify the priorities of the individual. The moment, when an individual's priorities were deliberated it makes employees see where they intersect with organizational goals (Kaur \& Randhawa, 2021). The familiar management tool viz. Management-by-objectives (MBO) enumerated that the employees should be driven to work with/for a common goal. (Drucker, 1954) popularized the concept of MBO through his book 'The Practice of Management. It conveys the objectives of the organization within the organization and then plow-in tools to adopt it commonly among all employees. It is understood that this allows the line managers to retrieve the work from workers without giving consistent directions. Here when individual priorities are synchronized with organizational goals, then it is considered a rightful approach.

Similar to MBO, there are several management tools to improve the efficacy of individuals to improve organizational efficiency. Overall, the purpose is to get the best out of employees and attach their organizational goals.

\subsection{Phenomenon of Salary}

If offered what's demanded in high, then the prerequisite to fetch the offer will be the motive. One such trade was the concept of salary. It is well known that Salary is a term derived from a Latin glossary salarium, which means 'salt'. In ancient days, salt was in huge demand. Hence, if someone does work salt was offered to reciprocate the gratitude. Gradually, it became a right to claim salt for every work that is accomplished. Then this right transformed as policy in both businesses and kingdoms. Still now in the 21 st century, this concept of salary is been carried. Salary is considered a powerful reward among all compensations (Park \& Conroy, 2020). The major gap is, to determine or fix the scale for work. How would one fix USD 3500 per month as salary to a software engineer and fix USD 1250 per month as salary to payroll personnel? On what basis? The rationale behind this is unclear. If it's about demand and supply of talents, then scavengers are to be paid more than project managers. If it's about qualification, doctoral degree holders are to be paid more than machinelearning experts. In the least case, if it's about talent, then skilled profile jobs are to be paid more than knowledgeable profile jobs (Biele et al., 2009). Complete chaos has happened and organizations fix the scale based on their terms. The tragedy here is, the employee presumes his or her PayScale with this prior experience. It would be fortunate if they get similar or higher scale, but the trend is usually negative, that is, people find it difficult to get similar PayScale in their jumps. And the pandemic situation in 2020-2021, studies prove that both organization and employees are in two different extremes, whereby the former identifies to cut cost and latter wants to improve income (Kaur \& Randhawa, 2021). Had there been a systematic rubric on fixing salaries, these wouldn't have happened. The world today has several significant systems of policies. Regretfully, there are no common formulae for calculating salary (Stiegert et al., 2021). Arguments claiming that it cannot be common due to differences in industries, organization, talents etcetera have to be quashed because the salaries cannot be based upon these above. It has to be based on an individual's outcome irrespective of any elements. But the experts have argued like, to achieve a task, how much can an organization pay? To accomplish the target, how much can an organization compensate from their budget as remuneration? To fulfill the goal, how much can an organization fix the pay? These experts are answerable for the chaos now. In a way, these experts are answerable for an organization's dip in efficacy.

Two vital factors can deteriorate an organization. One is high competition and the other is weak-manpower. If manpower is not nurtured or maintained properly then it's a failure. An important aspect in nurturing manpower is compensation \& rewards. One cannot refuse this fact. The underlying fact is, this stands as a motivator too.

\subsection{Phenomenon of Incentives}


The concept of Incentives is not new. Usually, this is discussed under motivation. A reward of remuneration payable on achieving a task is called an incentive. This works better if there is a need to replace salaries (Afridi et al., 2020). However, the idea was not to withheld salaries. Off later from 2020 , the majority of multinational companies have started embracing this concept.

It was Coca-Cola and General Electric (GE) in the 1920s started the practice of incentives (Bouranta et al., 2019). They hired people and set targets individually. These hired people were not on a payroll, however, they were holding the identity of the company and exerted the tasks. For keeping the competition between them, the companies started to reward cash more than what was committed. This made performance contagious and the entire salesforces started performing efficiently. No boss, no workplace, no holiday approval needed but still, people were able to get paid beyond their expectations (Tsourvakas \& Yfantidou, 2018). For companies, this model worked because none of their salespeople were non-productive. If by any chance anyone is non-productive, the individual will not be a salesperson. Again, there was no space for legalities to intervene for terminating them, as the entire process was without any offer letters (Chi et al., 2018). This model started spreading to all leading companies in those days and got titled as 'Incentives'. At one point in time, the supply \& demand of manpower along with economic depression, made these bonuses and incentives to be in limelight. People preferred it. It was the inception of anonym 'no pain, no gain', and efficacy of productivity was above the par. But eventually, this model was nullified due to a change in lifestyle of people where they conceived to earn more by working less. So, salaries were back on track than incentives. Still today in the 21 st century, organizations carry out a mixed strategy in compensation (Wamba et al., 2017).

\subsection{Research Objectives and Questions}

$\mathrm{RO}_{1}$ - To comprehend whether Salaries play a crucial role in determining the output of an employee?

$\mathrm{RO}_{2}$ - To critically evaluate equivalent elements for salaries that can convince employees for best output?

$\mathrm{RO}_{3}$ - To determine the role of institutional policies in an organization for determining compensation?

Research Question

$\mathrm{RQ}_{1}$ - Whether Salaries play a crucial role in determining the output of an employee?

$\mathrm{RQ}_{2}$ - What are equivalent elements for salaries that can convince employees for best output?

$\mathrm{RQ}_{3}$ - What is the role of institutional policies in an organization for determining compensation?

\subsection{Theoretical Framework}

Several theories in Human Resource Management relay a unified synonym, that is, to optimize the resource (manpower) (Harney \& Collings, 2021). This could be through motivation, training, rewards etcetera. Equity Theory was developed by J. Stacy Adam during the 1960s. This theory claims that the output of an individual can / should be measured by the inputs given on respective exertion. In simpler terms, inputs can be as each employee's contributions or rewards, whereas, outputs are consequences with another. Adams insists that input has to equivalent to output (or) rewards has to be equivalent to accomplishment's value. The more the closeness of output and input, the higher is the satisfaction for employees. This astounding theory stood as a strategy for organizations to fix the pay scale for their personnel. Figure 2 is a pictorial representation of Equity Theory.

Based on the types of rewards illustrated in Fig. 3, the direct rewards are examined in this research by analyzing their covariance and correlation of indicators. The literature of each of these direct rewards is highlighted in the following section.

\subsection{Literature Review: Salary fixation}

An organization will opt to follow particular remuneration-regulation to minimize cost or to maximize profit, or for both. The general thumb rule for calculating salary is (Almusaddar et al., 2018),

$$
S=S(F S, C S)
$$

Whereas represents salary, FS represents functions of sales and CS represents consumer satisfaction (Kalra et al., 2003). The organization offers any permutation and combination of compensation such as commission, salaries, task-based commission, incentives etcetera for the sole purpose of maximizing the bottom-line, that is, profit. any combination of salary, sales commission, and satisfaction-based commission to maximize profit. All the above elements have their own merits when it comes to evaluation. Several Human Resource experts claim that salaries are considered a significant strategy among all, to attract best-output from employees (Biele et al., 2009). Through this research, this is been challenged. Not for the sake of challenging, but for identifying whether this is still a better strategy post-2020 pandemic era and post-2019 IR 4.0 era.

\subsection{Incentive Fixation}

According to Bayesian equilibrium, the organization upgrades the employee's compensation scheme based on performance. Employees are offered additional compensation by comparing the increased sales done by individuals. In the context of this research, the salaries will motivate the person to maximize their interactive time with prospective consumers and consequently maximize the pre-sales exertions as described by Parasuraman in SERVQUAL theory (Kar, 2016). The purpose of Task-based incentives goes one step higher by ensuring that employees would consistently focus on pre-sales and post-sales exertion, like responding to customer's queries, sorting out any administrative concerns, etcetera. Further to that, it is understood that both salaries and task-based incentives stand as mechanisms to upgrade the productivity of employee's performance in an organization (Kishore et al., 2013).

Page 3/15 


\subsection{Compensation}

The process of Compensation is based upon philosophies in Compensation and strategies that include policy, structure, procedure, and principle on providing appropriate returns to employees or stakeholders in terms of pay or benefits (Rosolen \& Maclennan, 2016). He also claims that this process constitutes measuring the job value and maintain the pay pattern. Determining factors for compensation are the performance of the employee, the competence of the employee, skills of the employee., etcetera. If these are transposed to equivalent benefits, then the process of compensation is complete. It has to be noted that compensation is merely not only about cash or money. This is wider than financial rewards. Several types of research are done on non-financial compensation and those have become eye-openers for Human Resource Managers (Kim et al., 2017)

(Afridi et al., 2020) claims that compensation is a core element in human resources activity. If the principles are properly laid, then there could be evident productivity in the company. It is the responsibility of the HR department to concurrently revise the compensation \& benefits strategies depending upon growth or any internal factors in the organization. Since these deal with individual performance, there has to be an extensive interaction between employees and employers to arrive at compensation-slab. According to (Bouranta et al., 2019) compensation range enumerates the span between lower and higher PayScale of salary in the organization. The range of salaries in an organization is represented with grades of employment level which indicates the job value in the market. These are reviewed periodically as shown in Table 1.

Table 1

Review of Salary Structure Range

\begin{tabular}{|c|c|c|c|c|c|}
\hline \multirow[t]{2}{*}{ Job Level } & \multicolumn{5}{|c|}{ Percent of Companies } \\
\hline & Annually & Every Two Years & Every Three Years & Other/ Varies & $\begin{array}{l}\text { No Formal Ranges for } \\
\text { Job Level }\end{array}$ \\
\hline Top executives & $60 \%$ & $8 \%$ & $5 \%$ & $8 \%$ & $19 \%$ \\
\hline Nonexecutives & $77 \%$ & $9 \%$ & $7 \%$ & $6 \%$ & $1 \%$ \\
\hline
\end{tabular}

\subsubsection{Exploring Compensation and Benefits}

The organization recruits' employees to become part of the team to achieve organizational objectives and employees join the organization to gain monetary rewards as cash or other benefits to growing in their career. One of the greatest factors, why individuals get employed in companies rather than embarking on their own business, is due to fixed earning of rewards consistently (Arkin, 2008). Apart from the company's notoriety and work profile, the cash advertised as compensation is urgent in drawing in individuals to work for the organization. The more the stipend and benefits are advertised to workers, the more is their commitment, inspiration to work and do well. In any case, companies that offer lesser compensations see a tall whittling down rate and less efficiency from workers (Bhaumik et al., 2019). All these components offer assistance in making recompense and benefit an imperative figure in overseeing the workforce. Pay rates for employees are fixed by a few parameters like academic qualification, work experience etcetera. While hiring personnel for the Management team, abilities like leadership, networking with industry, communication skills etcetera are considered (Eklinder-frick \& Åge, 2020). Compensation has few ingredients such as variable pay, fixed pay and certain benefits. Figure 4 depicts the elements of compensation.

\subsection{Commission}

Commissions are considered as one of the common compensations to pay employees for obtaining consistent performance. The motive is to spread the organizational intention that the organization wants to create a solid reward for their employees to engage their best output in the prescribed job or task. The industry norm is $5 \%$ of total order billing, however, this depends upon the industry and organization. Among all compensation elements, the commission is a stronger motivator to perform more among employees (Kishore et al., 2013). If employees are assigned a task to accomplish in a stipulated period, a few of the coherent tasks may not be explicitly included in the calculation of compensation. This could be either because of unavailability of task-value or could be due to intentional cut in the framework of compensation devising strategy (Neessen et al., 2021). Whatsoever, it is important to fix a value (preferably in monetary value) for each sub-task, this not only will enable to understand the process but also makes the process transparent (Urrila, 2021). By all means, the commission is regarded as a solid compensation scheme. The primary or only demerit is, the commission is not consistent like salaries. So, people tend to avoid getting commission and therefore become an employee of an organization to have sustainable income irrespective of sales or output, or performance. Below Fig. 5 illustrates how the commission has an edge over bonuses (Kishore et al., 2013)

It is a fallacy of assumption to assume that the highest paid jobs are the best performing industry. It is also a myth to assume that the demand and supply of manpower determine the value-fixation of compensation to them (Flepp et al., 2021). Following Table, 1A illustrates the fact that the highest paid jobs not necessarily be the most performing industry. 
Table 1

A - Top 50 High paid Job versus Industry

\begin{tabular}{|c|c|c|c|c|}
\hline & Occupation & Annual Wage & Industry & Growth Rate (2020) \\
\hline 1 & Anesthesiologists & $\$ 266,000$ & Health Care & $0.34 \%$ \\
\hline 2 & Surgeons & $\$ 251,900$ & Health Care & $0.34 \%$ \\
\hline 3 & Oral and Maxillofacial Surgeons & $\$ 242,700$ & Health Care & $0.34 \%$ \\
\hline 4 & Obstetricians and Gynecologists & $\$ 235,200$ & Health Care & $0.34 \%$ \\
\hline 5 & Orthodontists & $\$ 229,400$ & Health Care & $0.34 \%$ \\
\hline 6 & Psychiatrists & $\$ 216,100$ & Health Care & $0.34 \%$ \\
\hline 7 & Physicians and Surgeons, All Other & $\$ 211,400$ & Health Care & $0.34 \%$ \\
\hline 8 & Family and General Practitioners & $\$ 208,600$ & Health Care & $0.34 \%$ \\
\hline 9 & Dentists, All Other Specialists & $\$ 200,000$ & Health Care & $0.34 \%$ \\
\hline 10 & Internists, General & $\$ 198,400$ & Health Care & $0.34 \%$ \\
\hline 11 & Prosthodontists & $\$ 197,000$ & Health Care & $0.34 \%$ \\
\hline 12 & Chief Executives & $\$ 196,100$ & Industrials & $0.18 \%$ \\
\hline 13 & Pediatricians, General & $\$ 187,500$ & Health Care & $0.34 \%$ \\
\hline 14 & Dentists, General & $\$ 174,100$ & Health Care & $0.34 \%$ \\
\hline 15 & Nurse Anesthetists & $\$ 169,500$ & Health Care & $0.34 \%$ \\
\hline 16 & Airline Pilots, Copilots, and Flight Engineers & $\$ 161,300$ & Services & $0.11 \%$ \\
\hline 17 & Petroleum Engineers & $\$ 154,800$ & Energy & $0.76 \%$ \\
\hline 18 & Computer and Information Systems Managers & $\$ 149,700$ & IT & $1.04 \%$ \\
\hline 19 & Podiatrists & $\$ 148,500$ & Health Care & $0.34 \%$ \\
\hline 20 & Architectural and Engineering Managers & $\$ 146,300$ & Real Estate & $0.10 \%$ \\
\hline 21 & Marketing Managers & $\$ 145,600$ & Industrials & $0.18 \%$ \\
\hline 22 & Financial Managers & $\$ 143,500$ & Financials & $0.13 \%$ \\
\hline 23 & Lawyers & $\$ 141,900$ & Services & $0.11 \%$ \\
\hline 24 & Sales Managers & $\$ 137,700$ & Services & $0.11 \%$ \\
\hline 25 & Natural Sciences Managers & $\$ 133,700$ & Energy & $0.76 \%$ \\
\hline 26 & Compensation and Benefits Managers & $\$ 130,000$ & Financials & $0.13 \%$ \\
\hline 27 & Law Teachers, Postsecondary & $\$ 129,800$ & Education & $0.17 \%$ \\
\hline 28 & Public Relations and Fundraising Managers & $\$ 127,700$ & PR., Comm. & $0.89 \%$ \\
\hline 29 & Personal Financial Advisors & $\$ 124,100$ & Financials & $0.13 \%$ \\
\hline 30 & Advertising and Promotions Managers & $\$ 123,900$ & PR., Comm. & $0.89 \%$ \\
\hline 31 & Human Resources Managers & $\$ 123,500$ & Services & $0.11 \%$ \\
\hline 32 & General and Operations Managers & $\$ 123,500$ & Industrials & $0.18 \%$ \\
\hline 33 & Physicists & $\$ 123,100$ & Health Care & $0.34 \%$ \\
\hline 34 & Health Specialties Teachers, Postsecondary & $\$ 122,900$ & Health Care & $0.34 \%$ \\
\hline 35 & Purchasing Managers & $\$ 121,800$ & Services & $0.11 \%$ \\
\hline 36 & Pharmacists & $\$ 121,700$ & Health Care & $0.34 \%$ \\
\hline 37 & Judges, Magistrate Judges, and Magistrates & $\$ 121,100$ & Services & $0.11 \%$ \\
\hline 38 & Air Traffic Controllers & $\$ 120,300$ & Services & $0.11 \%$ \\
\hline 39 & Computer Hardware Engineers & $\$ 119,700$ & IT & $1.04 \%$ \\
\hline 40 & Computer and Information Research Scientists & $\$ 119,600$ & IT & $1.04 \%$ \\
\hline
\end{tabular}

Source - (Fox Business, 2020) 


\begin{tabular}{|lllll|}
\hline & Occupation & Annual Wage & Industry & Growth Rate (2020) \\
\hline 41 & Optometrists & $\$ 119,100$ & Health Care & $0.34 \%$ \\
\hline 42 & Training and Development Managers & $\$ 117,700$ & Education & $0.17 \%$ \\
\hline 43 & Aerospace Engineers & $\$ 115,300$ & Industrials & $0.18 \%$ \\
\hline 44 & Actuaries & $\$ 114,900$ & Financials & $0.13 \%$ \\
\hline 45 & Economics Teachers, Postsecondary & $\$ 114,800$ & Education & $0.17 \%$ \\
\hline 46 & Managers, All Other & $\$ 113,200$ & Industrials & $0.18 \%$ \\
\hline 47 & Economists & $\$ 112,700$ & Financials & $0.13 \%$ \\
\hline 48 & Chemical Engineers & $\$ 112,400$ & Industrials & $0.18 \%$ \\
\hline 49 & Software Developers, Systems Software & $\$ 111,800$ & IT & $1.04 \%$ \\
\hline 50 & Medical and Health Services Managers & $\$ 111,700$ & Health Care & $0.34 \%$ \\
\hline Source - (Fox Business, 2020) & & & \\
\hline
\end{tabular}

From the above table, it could be understood that fixation of compensation is not done based on the organization's performance in revenue generation, whereas, it's based on the market value of a particular skill set. Hence, if the market value is set for every skill-set as industry practice, then every organization has to make exact revenue. Though this is a prerogative to be as a theory, it is next thing to impossible to witness it. For instance, assuming all other things remaining the same, there are two similar skill-sets (a) and (b) is fixed to receive $\$(n)$ for their employment in two different organizations respectively as $(x)$ and $(y)$, then the bottom-line of both $(x)$ and $(y)$ should be exactly same because the skill-sets deployed in same and their value is same (Harney \& Collings, 2021). But this never happens. Never history of business, it is found two similar companies in one industry generate similar revenue because of deploying similar skill-set of employees (with ceteris paribus).

\subsection{Research Framework}

Based on the theoretical framework (illustrated in Figs. 2B and 2C), the following conceptual framework is constructed for this research. The latent constructs are formulated after a thorough literature review. Institutional policies are denoted as policies and hypothesized as moderating variables, whereas the fixedsalary, task-based incentives, commission are hypothesized as independent variables. The target or outcome variable or dependent variable is improvising compensation and benefits. Below Fig. 6 illustrates the conceptual framework of this research and Fig. 7 illustrates the covariance between each latent construct that is to be measured in the following sections.

\subsection{Hypothesis}

$\mathrm{H}_{1}$ Fixed Salary has a significant relationship with Improvising compensation and benefits

$\mathrm{H}_{2}$ Task-based incentives have a significant relationship with improvising compensation and benefits

$\mathrm{H}_{3}$ Commission has a significant relationship with improvising compensation and benefits

$\mathrm{H}_{4}$ Policies has a moderating effect with improvising compensation and benefits when measured with task-based incentives

\subsection{Research Methodology}

A concurrent mixed-mode method was executed for this research. The rationale for using the concurrent mixed-mode method is due to the velocity of its impact. With a singular approach, the recommendations cannot be accurate thus both quantitative and qualitative were adhered to. Importantly, both were done simultaneously to avoid differences in the period of observation. A sample of 15 respondents was considered for a qualitative method based on (Morse, 1994). And 162 respondents were considered for a quantitative method based on (Krejcie \& Morgan, 1970), as the population of 280 employees was identified in four different sectors such as banking, education, Information Technology, and manufacturing companies in Singapore. Singapore is considered as one of the main hubs for business (Raju, 2018), thus the geography of Singapore was chosen to collect data from respondents. A proportionate stratified random sampling technique was used to select respondents, that is, $25 \%$ from each stratum (sector in this research) were taken to arrive population. Further to that, Krejcie and Morgan's table for sample size calculation was used to arrive at final respondent numbers.

In this research, demographics and descriptive statistics are not listed as it has less relevance. The focus was more on structural equation modeling, as moderation testing is considered as important to arrive at the recommendation (Ringle, C. M., Wende, S., and Becker, 2015). A revolutionary or challenging topic requires solid proof to justify its significance (Raju, 2021), hence the process in each phase is vital. If policies tend to have a significant role to impact the compensation while measuring task-based incentives, then it could lead to a big finding.

\subsection{Data Analysis}

As mentioned in the previous section, PLS-SEM (partial least square-structural equation modeling) analysis is done to measure and assess the indirect effects, direct effects, and moderation effects. SmartPLS 3.3.3 (Ringle, C. M., Wende, S., and Becker, 2015) version is used to analyze the data. 


\subsection{Measurement Model}

The measurement model is used to compute the reliability, composite reliability, convergent validity, and discriminant validity. Following Fig. 9 is the path coefficient of the research model

\subsubsection{Reliability and Validity}

Further to Table 2, the construct reliability and validity are illustrated in Table 3 which is derived from SmartPLS analytical tool.

Table 2

- Base Data

\begin{tabular}{|ll|}
\hline Data file Settings & \\
\hline Data file & 162 records \\
\hline Missing value marker & none \\
\hline Data Setup Settings & Mean Replacement \\
\hline Algorithm to handle missing data & - \\
\hline Weighting Vector & \\
\hline PLS Algorithm Settings & Mean 0, Var 1 \\
\hline Data metric & 1.0 \\
\hline Initial Weights & 300 \\
\hline Max. number of iterations & 7 \\
\hline Stop Criterion (10^-X): & No \\
\hline Use Lohmoeller settings? & Factor \\
\hline Weighting scheme & (Source - Output extracted from SmartPLS analytical tool) (Ringle, C. M., Wende, S., and Becker, 2015) \\
\hline
\end{tabular}

The above table is a prelude of setting in the analytical tool, viz. SmartPLS 3.3.3. Total respondents were 162 for quantitative and for the PLS algorithm the maximum iteration kept was 300 with the stop criterion of 7 . To calculate the measurement model, a path weighting scheme is not considered, hence the factoring scheme was chosen.

Table 3

- Construct Reliability and Validity

\begin{tabular}{|lllll|}
\hline & Cronbach's Alpha & rho_A & Composite Reliability & Average Variance Extracted (AVE) \\
\hline Commission & 0.956 & 0.957 & 0.966 & 0.849 \\
\hline Fixed Salary & 0.962 & 0.970 & 0.971 & 0.870 \\
\hline Improvising_Compensation_Benefits & 0.943 & 0.944 & 0.957 & 0.816 \\
\hline Moderating Effect 1 & 0.979 & 1.000 & 0.980 & 0.665 \\
\hline Polices & 0.964 & 0.966 & 0.972 & 0.875 \\
\hline Taskbased_Incentives & 0.950 & 0.952 & 0.963 & 0.838 \\
\hline (Key to Path Coefficient: Fixed Salary - FS; Task-based Incentives - IN; Commission - CM; Policies - PO; Improvising Compensation Benefits - CB) & & & \\
\hline (Source - Output extracted from SmartPLS analytical tool) & & & \\
\hline
\end{tabular}

According to (Joe F. Hair et al., 2014) if Cronbach alpha is above 0.70 , then the respective construct is considered reliable. Reliability here denotes the consistency of items or indicators. All constructs in this research are reliable as all values are above 0.70 . The composite reliability for all constructs is also above 0.70 in this research. AVE (average variance extracted) is the convergent validity, that is to assess the accuracy of the research instrument. (Joe F. Hair et al., 2014) suggests that 0.85 and above are valid items. In this research the values of AVE are nearer to 0.85 hence it can be understood that items or questions were having intersection points or minor similarities. 
Table 4

- Discriminant Validity (Fornell Larcker Criterion)

\begin{tabular}{|c|c|c|c|c|c|c|}
\hline & Commission & $\begin{array}{l}\text { Fixed } \\
\text { Salary }\end{array}$ & Improvising_Compensation_Benefits & $\begin{array}{l}\text { Moderating } \\
\text { Effect } 1\end{array}$ & Polices & Taskbased_Incentives \\
\hline Commission & 0.922 & & & & & \\
\hline Fixed_Salary & 0.979 & 0.933 & & & & \\
\hline Improvising_Compensation_Benefits & 0.962 & 0.932 & 0.903 & & & \\
\hline Moderating Effect 1 & 0.334 & 0.306 & 0.365 & 0.815 & & \\
\hline Polices & 0.966 & 0.987 & 0.919 & 0.378 & 0.935 & \\
\hline Taskbased_Incentives & 0.938 & 0.966 & 0.905 & 0.280 & 0.964 & 0.915 \\
\hline
\end{tabular}

The values of discriminant validity should be above 0.85 according to (Fornell \& Larcker, 1981). This is arrived at by the square root of AVE for that particular construct. Moreover, as a thumb rule, the value of a particular construct should always be higher than the remaining constructs. For example, in above Table 6 , the value of moderating effect 0.815 which is greater than other sub-value of other constructs.

\subsection{Structural Model}

The structural model is to assesses the relationship between the latent construct's covariance (Raju \& Phung, 2020). Among few calculations, the predominant assessments are R square, Moderation analysis, Mediation analysis, and Path coefficients (Raju, 2021).

\subsubsection{R Square}

\begin{tabular}{|lll|}
\hline & R Square & R Square Adjusted \\
\hline Improvising_CompensationBenefits & 0.935 & 0.933 \\
\hline $\begin{array}{l}\text { Key to Path Coefficient: Improvising } \\
\text { (Source - Output extracted from SmartPLS anation Benefits - CB) }\end{array}$ \\
\hline
\end{tabular}

$\mathrm{R}$ square determines the variance of dependent variables explained by independent variables (Jospeh F. Hair, 2006). It is understood that the value above 0.75 is substantial, $0.50-0.74$ is moderate and anything below 0.02 is weak. In this research, the R square value is 0.935 , which can be considered excellent.

Table 5

- P-Value and Moderation Analysis

\begin{tabular}{|c|c|c|c|c|c|}
\hline & $\begin{array}{l}\text { Original Sample } \\
\text { (0) }\end{array}$ & $\begin{array}{l}\text { Sample Mean } \\
\text { (M) }\end{array}$ & $\begin{array}{l}\text { Standard Deviation } \\
\text { (STDEV) }\end{array}$ & $\begin{array}{l}\text { T Statistics } \\
\text { (|O/STDEV|) }\end{array}$ & $\begin{array}{l}\mathrm{P} \\
\text { Values }\end{array}$ \\
\hline Commission -> Improvising_Compensation_Benefits & 1.168 & 1.166 & 0.143 & 8.190 & 0.000 \\
\hline Fixed_Salary -> Improvising_Compensation_Benefits & -0.113 & -0.121 & 0.212 & 0.532 & 0.595 \\
\hline $\begin{array}{l}\text { Moderating Effect } 1 \text {-> } \\
\text { Improvising_Compensation_Benefits }\end{array}$ & 0.112 & 0.115 & 0.054 & 2.070 & 0.039 \\
\hline Polices -> Improvising_Compensation_Benefits & -0.392 & -0.376 & 0.184 & 2.131 & 0.034 \\
\hline $\begin{array}{l}\text { Taskbased_Incentives -> } \\
\text { Improvising_Compensation_Benefits }\end{array}$ & 0.274 & 0.270 & 0.050 & 5.526 & 0.000 \\
\hline
\end{tabular}

P-value is expected to be above 0.05 which means the probability of occurrence of a particular hypothesis is like to be $95 \%$. In Table 5 , it could be understood that all p-values are higher than 0.05 except Fixed Salaries $\diamond$ (towards) Improvising compensation and benefits, which is like 0.595 . Learning is, Fixed Salaries have less importance on compensation according to 162 respondents. 
Table 6

- Confidence Intervals

\begin{tabular}{|c|c|c|c|c|}
\hline & Original Sample (0) & Sample Mean (M) & $2.5 \%$ & $97.5 \%$ \\
\hline Commission -> Improvising_CompensationBenefits & 1.168 & 1.166 & 0.840 & 1.407 \\
\hline Fixed_Salary -> Improvising_CompensationBenefits & -0.113 & -0.121 & -0.529 & 0.254 \\
\hline Moderating Effect 1 -> Improvising_CompensationBenefits & 0.112 & 0.115 & 0.024 & 0.239 \\
\hline Polices -> Improvising_CompensationBenefits & -0.392 & -0.376 & -0.722 & -0.004 \\
\hline Taskbased_Incentives -> Improvising_CompensationBenefits & 0.274 & 0.270 & 0.168 & 0.364 \\
\hline
\end{tabular}

Table 7

- Phenomenological Analysis

\begin{tabular}{|c|c|c|}
\hline S.No. & Respondent View & $\begin{array}{l}\text { Collinearity with Fixed- } \\
\text { Salary }\end{array}$ \\
\hline 1. & Important, but depends upon the organization & Low \\
\hline 2. & Incentives are ideal & Low \\
\hline 3. & Task based incentives are risky and salaries are ideal & Mediocre \\
\hline 4. & Incentives leads to perform better & Low \\
\hline 5. & Salaries and incentives, both has to be part of compensation & High similarity \\
\hline 6. & If proper framework or strategy is devised for Task based incentives, then it is considerable & Mediocre \\
\hline 7. & It is not wise to debate between Salaries and Incentives. & Low \\
\hline 8. & Incentives rewards will make the employees work better & Low \\
\hline 9. & $\begin{array}{l}\text { Task based incentives are the only hope to sustain or rescue the organization from recurring losses in manpower } \\
\text { deployment }\end{array}$ & Low \\
\hline 10. & Salaries are safe haven and less risky than incentive scheme & Low \\
\hline 11. & Unable to conclude which of either should be practiced, however, this depends upon industries & High similarity \\
\hline 12. & More volunteering can happen with Task based incentives & Mediocre \\
\hline 13. & $\begin{array}{l}\text { Salary scheme are followed for long time in Business, its time to restructure the perception of compensation and } \\
\text { benefits }\end{array}$ & Mediocre \\
\hline 14. & $\begin{array}{l}\text { Task based incentives has not been practiced full-fledged in any organization, hence it is not worth to risk it in } \\
\text { business. }\end{array}$ & Low \\
\hline 15. & Possibilities of consistent revenue and profit margin will be high if Task based incentive scheme is following & Low \\
\hline
\end{tabular}

All above analytics were quantitative, whereas, phenomenological analysis is done to suffice qualitative approach. Following 5 questions (semi-structured interview) were asked to 15 respondents face-to-face in Malaysia,

1. Do you prefer to get a salary or incentives?

2. How does the process of compensation and benefits work in your firm?

3. How is the mentality of employees when salary is reduced?

4. Why not the organization pay for each task rather than a monthly salary?

5. What are the demerits of salary fixation and incentive fixation?

As this research is focusing on incentives as a better option compared to salaries, the phenomenon chosen was 'Task-Based Incentives'. The following analysis is done based on this phenomenon.

The common perception is, employees, feel compensation through salaries is less-risky and has the feature of job security. Despite this, it is identified that if companies or institutions want to survive, mere payment of salaries will not be helpful. Organizations will face stagnation at one point in time if salaries are alone rewarded to employees (Mohd Adnan \& Valliappan, 2019).

After qualitative data collection (interview) is done, the responses were categorized into 'favoring Salaries' and favoring task-based incentives. It is understood that the majority of respondents favored task-based incentives as best practices to revive the growth of the organization.

\subsection{Results and Findings}


Table 8

Hypothesis Test Result

\begin{tabular}{|lc|}
\hline Hypothesis & Result \\
\hline $\mathrm{H}_{1}$ Fixed Salary has a significant relationship with Improvising compensation and benefits & Negative \\
$\mathrm{H}_{2}$ Task-based incentives have a significant relationship with improvising compensation and benefits & Positive \\
$\mathrm{H}_{3}$ Commission has a significant relationship with improvising compensation and benefits & Positive \\
$\mathrm{H}_{4}$ Policies has a moderating effect with improvising compensation and benefits when measured with task-based incentives & Positive \\
\hline
\end{tabular}

Hypothesis testing is the most crucial part of any research. In this research, except fixed salaries vs. compensations, all other hypothesis is positive. The reason behind why 'salaries don't have significance to improvise compensation', is because people tend to see fixed salaries as a redundant element (Polas \& Raju, 2021). Hawthorne effect would have played a role to distract the meaning of questions in the questionnaire, that is, respondents would have assumed that the respective item is targeted to understand the notion of fixed-salary towards employee motivation rather than improvising compensation. This assumption is considered because, in general salaries cannot be eliminated in any circumstances from compensation. But in this research analysis, it was understood several respondents disagreed unanimously. This could be an outlier or a serious finding to be noted through this research. However, the researcher through this research, considers the latter i.e. abide with respondent's response. Companies need to focus on needs and requirements when it comes to devising policies for compensation and benefits. Salaries are a concern, at least from the post-2020 pandemic period (Flepp et al., 2021). It is time for companies to focus to compensate their employees based on task accomplishments.

\subsection{Conclusion}

Through this research, it is understood that task-based incentives are a rightful practice for companies to sustain their business engagements. Paying fixed salaries as per market standard is collateral damage to companies, particularly those that are inconsistent losses of more than five quarters (Stiegert et al., 2021). At the same time, compensation cannot be bought down publicly across all companies as it may spread negative emotions among the fraternity. The solution for the right balance is task-based incentives. This research identifies and submits the rationale for this. The limitations such as biased opinions, more sample size, geographical selection of respondents could have played a major role in this research, however, the unanimous answer from respondents were singular. It is time for a change in human resource practice. This empirical research shall stand as the pioneer to invite further researches in this area to either challenge or substantiate the findings.

\section{References}

1. Afridi, S. A., Afsar, B., Shahjehan, A., Rehman, Z. U., Haider, M., \& Ullah, M. (2020). Perceived corporate social responsibility and innovative work behavior: The role of employee volunteerism and authenticity. Corporate Social Responsibility and Environmental Management, 27(4), $1865-1877$. https://doi.org/10.1002/csr.1932

2. Almusaddar, A. A. S., Ramzan, S. R., \& Raju, V. (2018). the Influence of Knowledge, Satisfaction, and Motivation on Employee Performance Through Competence. International Journal of Business and General Management (IJBGM).

3. Arkin, R. C. (2008). Governing lethal behavior: Embedding ethics in a hybrid deliberative/reactive robot architecture - Part I: Motivation and philosophy. HRI 2008 - Proceedings of the 3rd ACM/IEEE International Conference on Human-Robot Interaction: Living with Robots, 121-128.

https://doi.org/10.1145/1349822.1349839

4. Bhaumik, A., Law, K. A., Jiemiao, F., \& Raju, V. (2019). Impact of globalization of firms: Descriptive study on performance on network ability. International Journal of Control and Automation, 12(5). https://doi.org/10.33832/ijca.2019.12.5.01

5. Biele, G., Rieskamp, J., \& Czienskowski, U. (2009). Explaining cooperation in groups: Testing models of reciprocity and learning $i$ [Organizational Behavior and Human Decision Processes 106 (2008) 89 ¿105] (DOI:10.1016/j.obhdp.2008.01.001). Organizational Behavior and Human Decision Processes, 108(2), 342-343. https://doi.org/10.1016/j.obhdp.2008.11.002

6. Bouranta, N., Psomas, E., Suárez-Barraza, M. F., \& Jaca, C. (2019). The key factors of total quality management in the service sector: a cross-cultural study. Benchmarking, 26(3), 893-921. https://doi.org/10.1108/BIJ-09-2017-0240

7. Chi, Y., Qin, Y., Song, R., \& Xu, H. (2018). Knowledge graph in smart education: A case study of entrepreneurship scientific publication management. Sustainability (Switzerland), 10(4). https://doi.org/10.3390/su10040995

8. Drucker, P. F. (1954). The Practice of Management. https://www.jstor.org/stable/4165976

9. Eklinder-frick, J. O., \& Åge, L. (2020). Relational business negotiation - propositions based on an interactional perspective. Journal of Business \& Industrial Marketing, 5(August 2019), 925-937. https://doi.org/10.1108/JBIM-04-2019-0169

10. Flepp, R., Meier, P., \& Franck, E. (2021). The effect of paper outcomes versus realized outcomes on subsequent risk-taking: Field evidence from casino gambling. Organizational Behavior and Human Decision Processes, 165, 45-55. https://doi.org/10.1016/j.obhdp.2021.04.003

11. Fornell, C., \& Larcker, D. F. (1981). Evaluating Structural Equation Models with Unobservable Variables and Measurement Error. Journal of Marketing Research, 18(1), 50. https://doi.org/10.2307/3151312

12. Fox Business. (2020). The highest-paying jobs in the world / Fox Business. The Fox Business. https://www.foxbusiness.com/lifestyle/the-10-highestpaying-jobs-in-the-world 
13. Guan, X., Liu, M., \& Meng, Y. (2021). A comprehensive ecological compensation indicator based on pollution damage - protection bidirectional model for the river basin. Ecological Indicators, 126, 107708. https://doi.org/10.1016/j.ecolind.2021.107708

14. Hair, Joe F., Sarstedt, M., Hopkins, L., \& Kuppelwieser, V. G. (2014). Partial least squares structural equation modeling (PLS-SEM): An emerging tool in business research. European Business Review, 26(2), 106-121. https://doi.org/10.1108/EBR-10-2013-0128

15. Hair, Jospeh F. (2006). Successful Strategies for Teaching Multivariate Statistics. Proceedings of the 7th International Conference on ..., 1-5.

16. Harney, B., \& Collings, D. G. (2021). Navigating the shifting landscapes of HRM. Human Resource Management Review, 100824. https://doi.org/10.1016/j.hrmr.2021.100824

17. Hewett, R., \& Shantz, A. (2021). A theory of HR co-creation. Human Resource Management Review, 100823. https://doi.org/10.1016/j.hrmr.2021.100823

18. Kalra, A., Shi, M., \& Srinivasan, K. (2003). Salesforce Compensation Scheme and Consumer Inferences. 49(5), 655-672.

https://d1 wqtxts1xzle7.cloudfront.net/40152460/Salesforce_Compensation_Scheme_and_Consu20151118-6687-3Iwn9j.pdf?1447879149=\&responsecontent-

disposition=inline\%3B+filename\%3DSalesforce_Compensation_Scheme_and_Consu.pdf\&Expires=1624450719\&Signature=XXiWk Kqu9tNKvC al4iiDIDu 58dDHpWU9 TGQnIG5IqJZ3jKovPPS7bhyaV1EH0U51824Ld-DB7MovrhwfNp9IfbE3dF5 OdQkgiAxjhz9n1l1iA3yXbFa9q2tw0nCM1e5HNL1xDVDR0p1EVUaZzcLp47fJMVFrW0TfsFWUHfNxgjoasbt-Y76CYQZZnfGHCpps1EoDC74DhxUxRK7vlrKugPf GnI0qAj6VOiro5Cs42t5H4

19. Kar, B. (2016). Service Quality and SERVQUAL Model: A Reappraisal. Amity Journal of Operations Management ADMAA, 1(2), 52-64.

20. Kaur, D. K., \& Randhawa, D. G. (2021). Exploring the influence of supportive supervisors on organizational citizenship behavior: Linking theory to practice. IIMB Management Review. https://doi.org/10.1016/j.iimb.2021.03.012

21. Kim, H. L., Rhou, Y., Uysal, M., \& Kwon, N. (2017). An examination of the links between corporate social responsibility (CSR) and its internal consequences. International Journal of Hospitality Management, 61, 26-34. https://doi.org/10.1016/j.ijhm.2016.10.011

22. Kishore, S., Rao, R. S., Narasimhan, O., \& John, G. (2013). Bonuses versus commissions: A field study. Journal of Marketing Research, 50(3), 317-333. https://doi.org/10.1509/jmr.11.0485

23. Krejcie, R. V, \& Morgan, D. W. (1970). DETERMINING SAMPLE SIZE FOR RESEARCH ACTIVITIES. EDUCATIONAL AND PSYCHOLOGICAL MEASUREMENT, 30, 607-610.

24. Lee, M., \& Kray, L. J. (2021). A gender gap in the managerial span of control: Implications for the gender pay gap. Organizational Behavior and Human Decision Processes, 167, 1-17. https://doi.org/10.1016/j.obhdp.2021.06.001

25. Mohd Adnan, S. N. S., \& Valliappan, R. (2019). Communicating shared vision and leadership styles towards enhancing performance. In International Journal of Productivity and Performance Management (Vol. 68, Issue 6). https://doi.org/10.1108/IJPPM-05-2018-0183

26. Morse, J.. (1994). Designing funded qualitative research. Handbook of Qualitative Research, 6(3), 220-235. https://psycnet.apa.org/record/1994-98625012

27. Neessen, P. C. M., de Jong, J. P., Caniëls, M. C. J., \& Vos, B. (2021). Circular purchasing in Dutch and Belgian organizations: The role of intrapreneurship and organizational citizenship behavior towards the environment. Journal of Cleaner Production, 280, 124978.

https://doi.org/10.1016/j.jclepro.2020.124978

28. Park, S., \& Conroy, S. A. (2020). Unpacking the evolving process of pay-for-performance system implementation. Human Resource Management Review, 100794. https://doi.org/10.1016/j.hrmr.2020.100794

29. Polas, M. R. H., \& Raju, V. (2021). Technology and Entrepreneurial Marketing Decisions During COVID-19. Global Journal of Flexible Systems Management. https://doi.org/10.1007/s40171-021-00262-0

30. Raju, V. (2018). Theory of Lim law: Leadership style. Eurasian Journal of Analytical Chemistry, 13(6), 125-136. https://www.scopus.com/record/display.uri?eid=2-s2.0-85063183042\&origin=inward\&txGid=1105711c191f9c2731bc7612fdb1ffae

31. Raju, V. (2021). Implementing Flexible Systems in Doctoral Viva Defense Through Virtual Mechanism. Global Journal of Flexible Systems Management, 22(1). https://doi.org/https://doi.org/10.1007/s40171-021-00264-y

32. Raju, V., \& Phung, S. P. (2020). Economic dimensions of blockchain technology: In the context of the extension of cryptocurrencies. International Journal of Psychosocial Rehabilitation, 24(2), 29-39. https://doi.org/10.37200/IJPR/V24I2/PR200307

33. Ringle, C. M., Wende, S., and Becker, J.-M. (2015). SmartPLS 3. In Boenningstedt: SmartPLS GmbH. http://www.smartpls.com

34. Rosolen, T., \& Maclennan, M. L. F. (2016). Strategic human resource management and corporate social responsibility: Evidence from Emerging Markets. Internet, 11(2), 66. https://doi.org/10.18568/1980-4865.11266-80

35. SHRM.ORG. (2019). Salary Structures: Creating Competitive and Equitable Pay Levels. Https://Www.Shrm.Org/Resourcesandtools/HrTopics/Compensation/Pages/Salarystructures.Aspx. https://www.shrm.org/resourcesandtools/hr-topics/compensation/pages/salarystructures.aspx

36. Stiegert, P., Täuber, S., Leliveld, M. C., \& Oehmichen, J. (2021). The stereotype rub-off effect - Organizational stereotypes modulate behavioral expectations, expectancy violation, and punishment after transgressions. Organizational Behavior and Human Decision Processes, 165, 127-138. https://doi.org/10.1016/j.obhdp.2021.04.011

37. Tsourvakas, G., \& Yfantidou, I. (2018). Corporate social responsibility influences employee engagement. Social Responsibility Journal, 14(1), $123-137$. https://doi.org/10.1108/SRJ-09-2016-0153

38. Urrila, L. I. (2021). From personal wellbeing to relationships: A systematic review on the impact of mindfulness interventions and practices on leaders. Human Resource Management Review, 100837. https://doi.org/10.1016/j.hrmr.2021.100837

39. Wamba, S. F., Gunasekaran, A., Akter, S., Ren, S. J. fan, Dubey, R., \& Childe, S. J. (2017). Big data analytics and firm performance: Effects of dynamic capabilities. Journal of Business Research, 70, 356-365. https://doi.org/10.1016/j.jbusres.2016.08.009

Page $11 / 15$ 
Figures

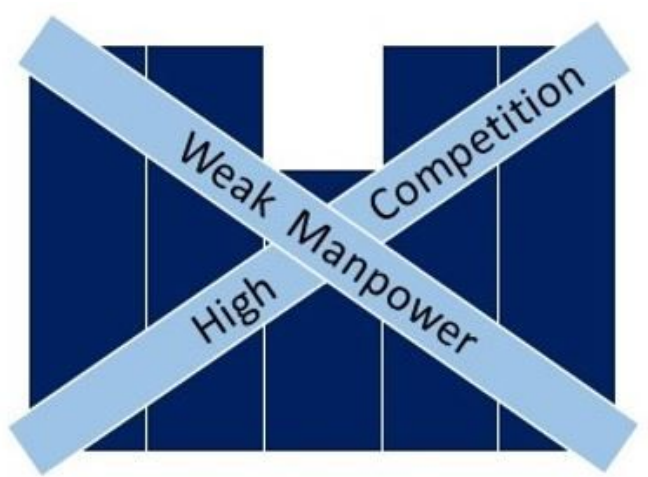

Figure 1

Organization Killer (Source: Author)

ADAM'S EQUITY THEORY

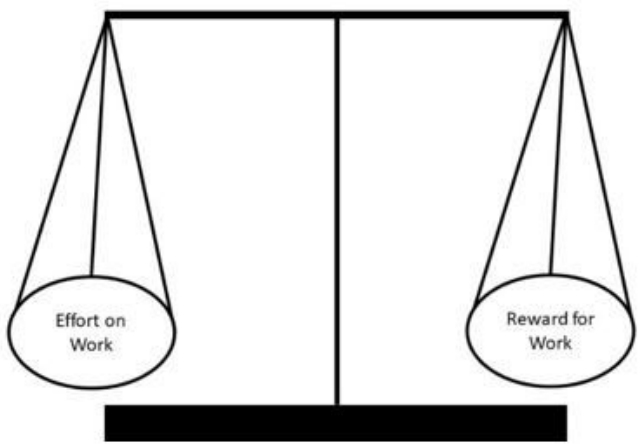

Figure 2

Equity Theory

TYPES OF REWARDS

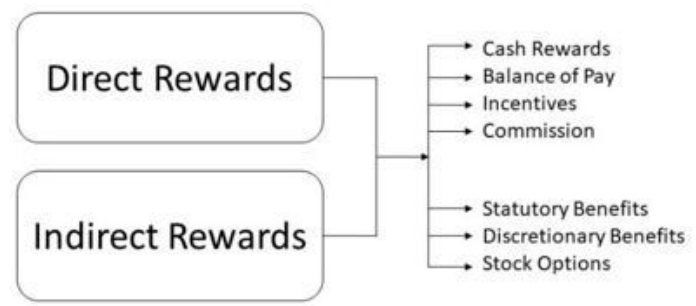

Figure 3

Types of Rewards (Kishore et al., 2013) 


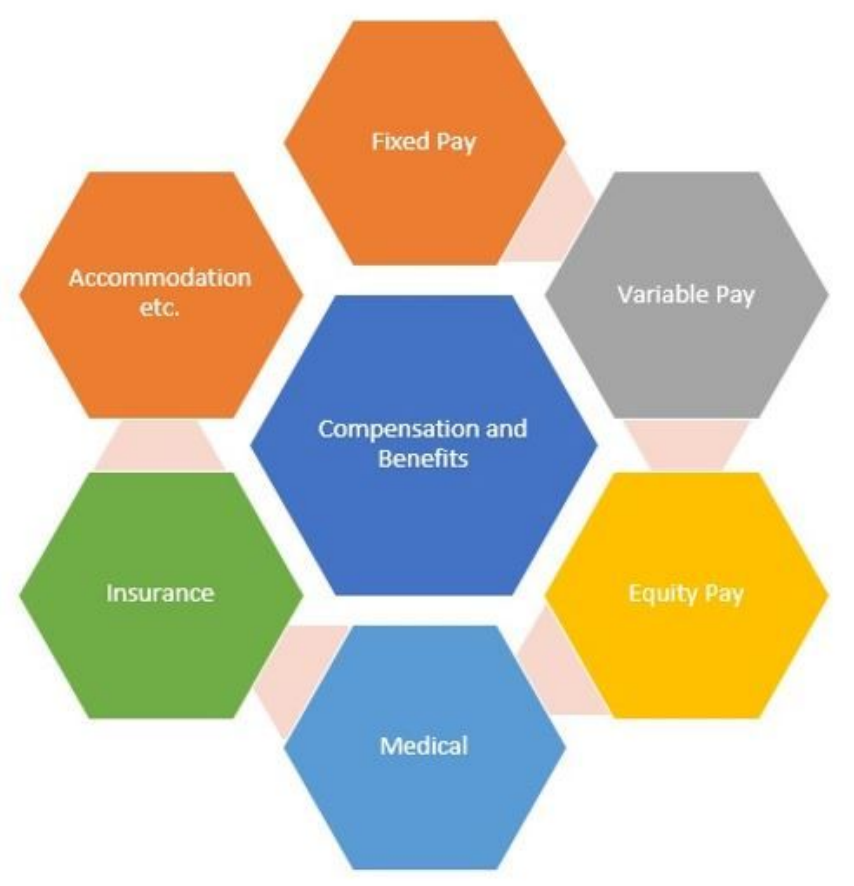

Figure 4

Elements of Compensation and Benefits (Guan et al., 2021)

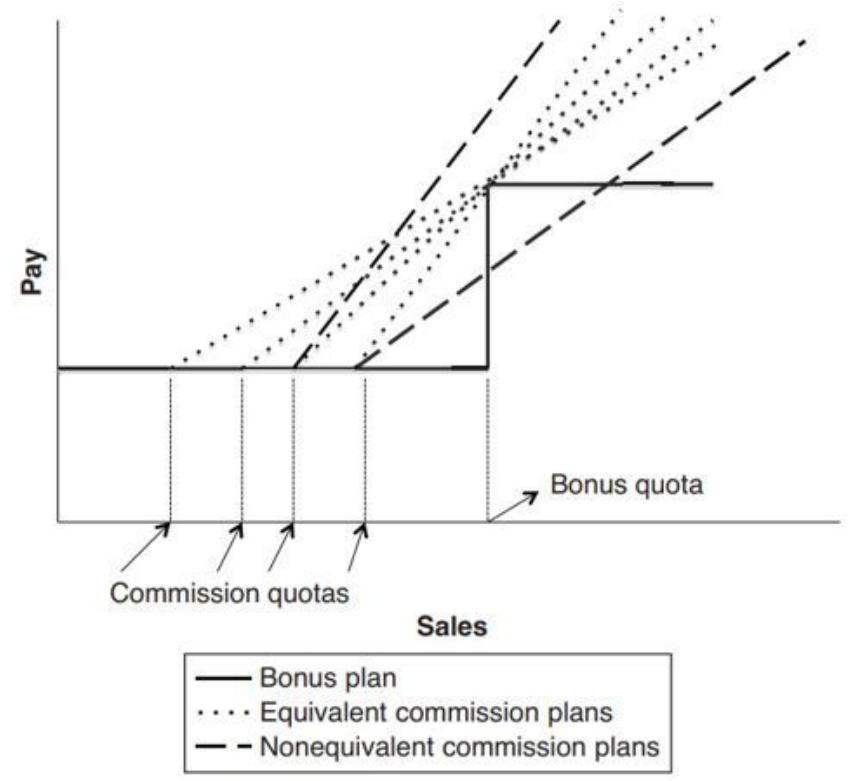

\section{Figure 5}

Plots of Incentive Compensation Plans (Kishore et al., 2013) 


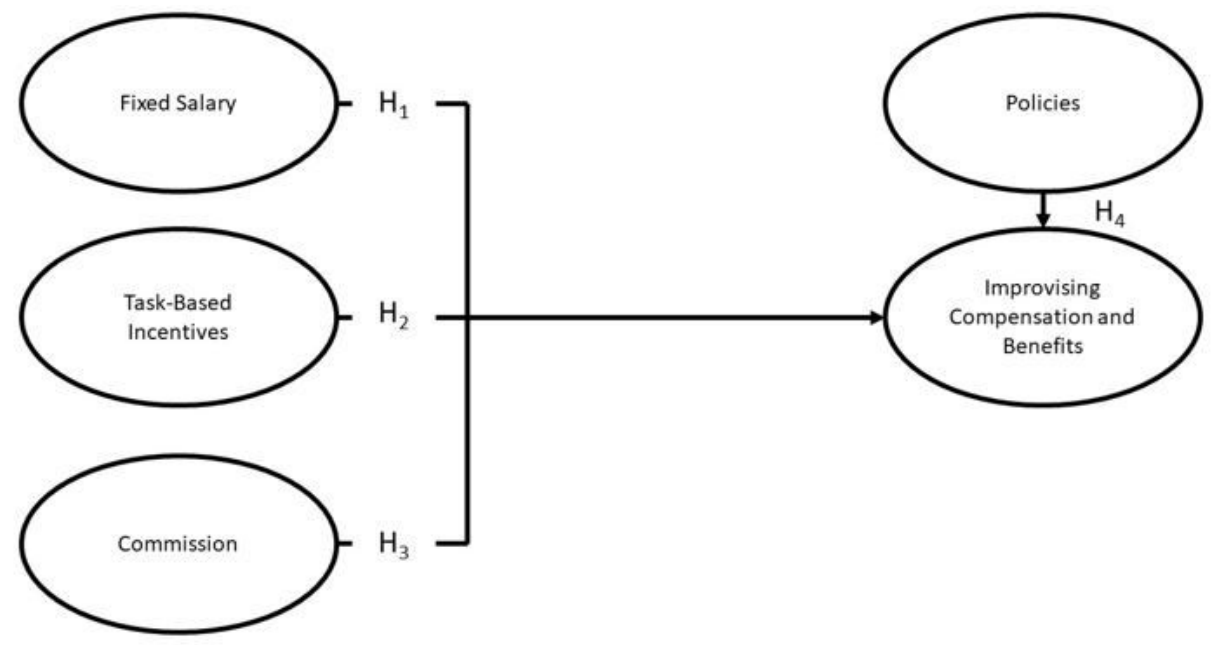

Figure 6

Research Framework for the respective study

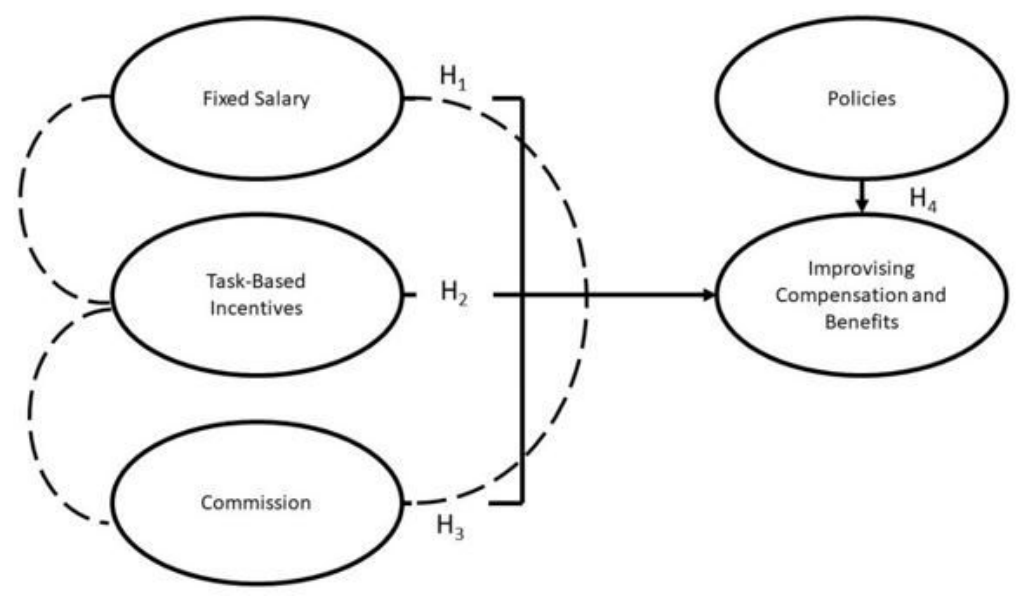

Figure 7

Covariance between Constructs

Proportionate Stratified Random Sampling Technique

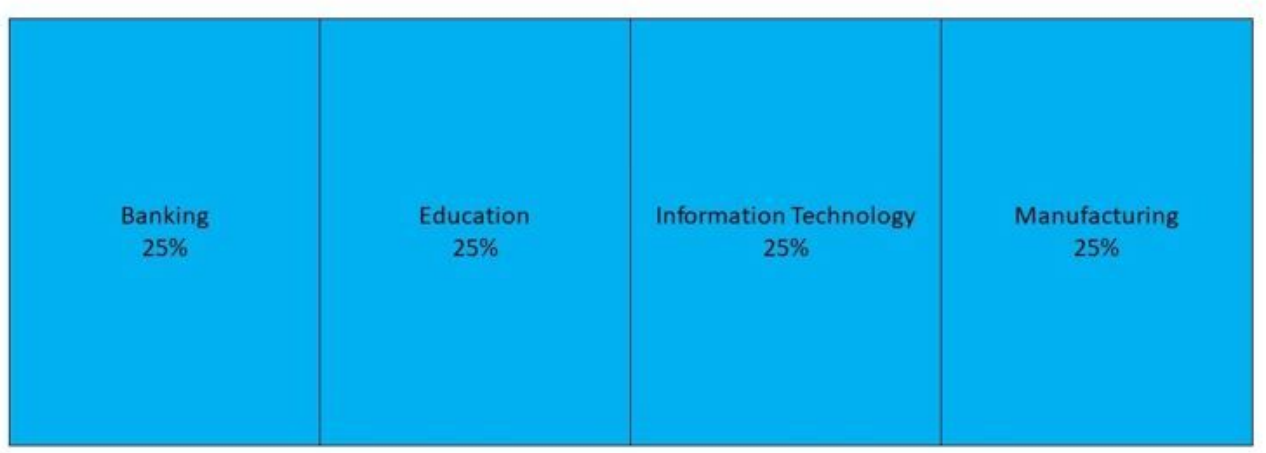

Figure 8

Sampling Technique 


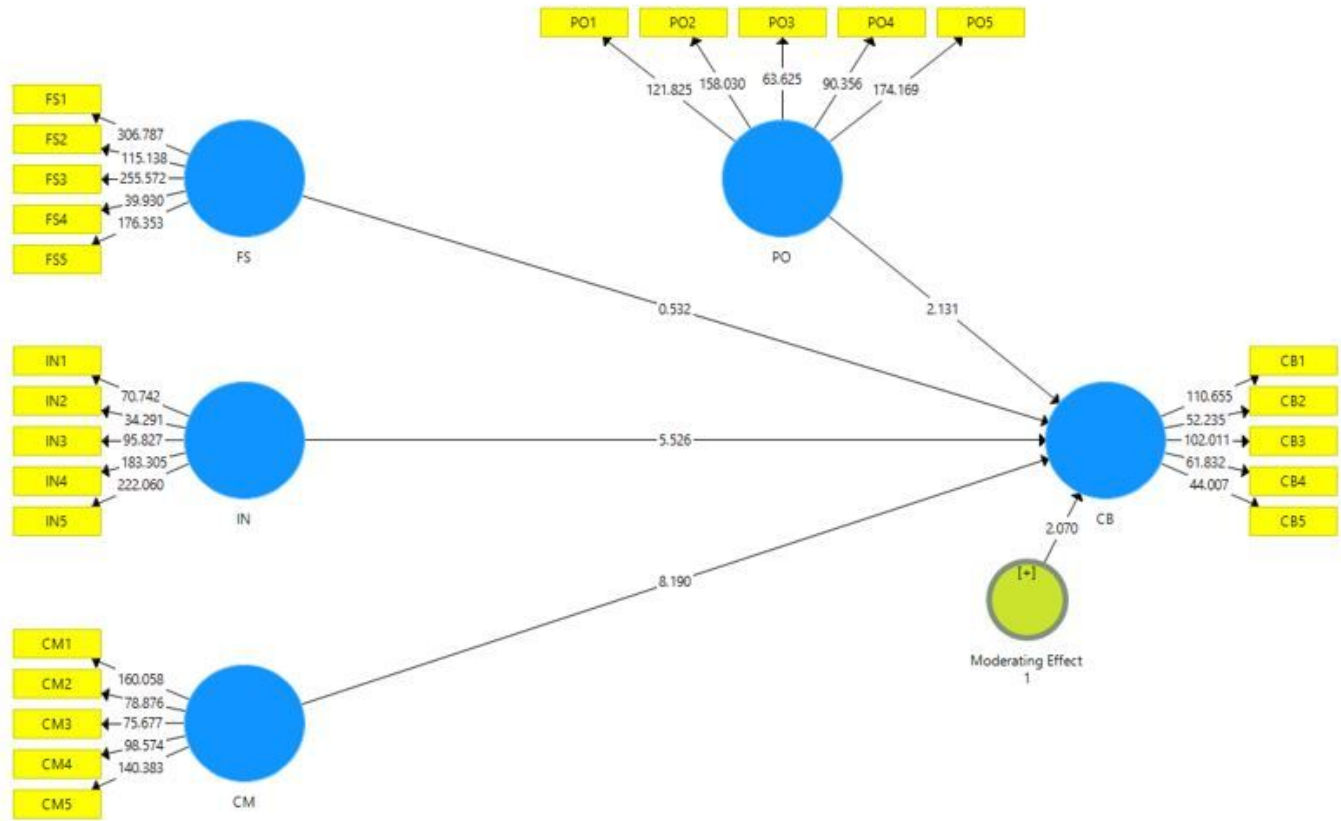

Figure 9

Path Diagram: Measurement Model 